\title{
Drawing Monsters with Emil Ferris and Lynda Barry: An Exploration of the Drawing Process as Part of Graphic Medicine
}

\author{
Susan M. Squier \\ Brill Professor Emerita of Women's, Gender, and Sexuality Studies and English, the \\ Pennsylvania State University, USA. \\ Einstein Visiting Fellow, Freie Universität Berlin, 2016-2021. \\ Email: susan.squier@gmail.com
}

\begin{abstract}
This essay explores the role of drawing as a mode of processing intersectional violence, a strategy that I argue links Emil Ferris's comic, My Favorite Thing is Monsters (2018) to Lynda Barry's pedagogical graphic narratives What It Is (2008) and Making Comics (2019). I argue that My Favorite Thing is Monsters embodies an enhanced version of graphic medicine that shifts the scale of analysis from the individual to the collective, revealing the health impact of intersectional oppressions. In its titular preoccupation with monsters, especially the Medusa, and its materialization of the protagonist's sketch book, I further argue that Ferris's work of fiction recalls Barry's exercise of drawing monsters. Continuing its exploration of the healing process of drawing, and drawing monsters, the essay concludes with an experiment in ethnographic criticism, reflecting on my own experience of drawing my way through the global pandemic of Covid-19 during the first six months of 2020 .
\end{abstract}

Keywords: Emil Ferris, Lynda Barry, Graphic Medicine, Intersectionality, anti-Semitism, racism, gendered violence, Sigmund Freud, Hélène Cixous, Medusa, scale, health, drawing, ethnographic criticism.

"I didn't want to be a woman-being a monster was the best solution." -

Emil Ferris (Thielman, 2017)

In Emil Ferris's 2018 graphic narrative ${ }^{1}$ My Favorite Thing is Monsters, ten-year-old Karen Reyes learns an important lesson from her older brother Deeze: "the best way to get through hard things is to draw your way through" (n.p.). Emil Ferris learned this lesson herself in 2002, when a bite from a mosquito gave her West Nile Virus, which left her paralyzed from the waist down. "So you created My Favorite Thing is Monsters after fighting your way back from paralysis that kept you from being able to draw" John Tumey of The Comics Journal told her in a 2017 interview. "You've written that art healed you. (Tumey, 2017). Ferris agreed,

"I was told by the Head of Neurology at a really major hospital that I would never walk again. He was quite sure that I wouldn't but I think the experience of going to the School of the Art Institute [of Chicago] was just what I needed" (Tumey, 2017).

(C) AesthetixMS 2021. This Open Access article is published under a Creative Commons Attribution Non-Commercial 4.0 International License (http://creativecommons.org/licenses/by-nc/4.o/), which permits non-commercial re-use, distribution, and reproduction in any medium, provided the original work is properly cited. For citation use the DOI. For commercial re-use, please contact editor@rupkatha.com. 
An autobiographical comic Ferris published in Chicago Magazine, "The Bite that Saved My Life" captures the way that art acted for Ferris as crucial medicine in a very dark time. "My daughter was right ... Art is Healing!" (2017). Ferris's graphic narrative draws on her own experience of having been born with scoliosis, which restricted her movement for much of her childhood. As she told the Arts and Culture beat in Chicago Magazine, "I was also severely hunchbacked, which is why I loved monsters" (2017). She further explained, "the origin for My Favorite Thing Is Monsters was a screenplay [I] wrote of "a werewolf lesbian girl being enfolded into the protective arms of a Frankenstein trans kid" (2017). I begin with these paratextual details to establish that if we go by a familiar definition of graphic medicine as "the use of comics to tell personal stories about health," My Favorite Thing is Monsters is definitely a work of graphic medicine. But the details about its screenplay origin and its focus on lesbian and trans, human and monstrous characters, reveal that Ferris's work is also distinctly multi-modal, and intersectional.

\section{The intersectional perspective of Monsters}

Emil Ferris's protagonist, ten-year-old Karen Reyes, has two great loves: horror stories and drawing. She loves Mary Shelley's Frankenstein, but also Greek and Roman myths, folktales about werewolves and eldriches, and arcane lore. And she loves drawing. She draws all sorts of monsters in her sketchbook: movie monsters, horror comic monsters, ancient Egyptian, Greek and Roman monsters, and classic literary monsters: Dracula, the Invisible Man, the Mummy, and the Wolfman. As we meet these monsters in the course of the graphic narrative, they sketch out Karen's inherently intersectional identity.

What do I mean by that? In 1989, Kimberlé Crenshaw formulated the concept of intersectionality to argue against the notion that identity is simple and unified. Instead, Crenshaw argued that identity is actually multiple, layered, and co-created, a product of structural, political, and even representational forces. Moreover, as Stephen Shapiro (2020) has recently argued, "the newer usage of intersectionality shifts the unit of analysis from the unit of the individual to that of the social collective, a social movement formed by an elective affinity among different groups each with their own particular kinds of exclusions." (126). The noteworthy accomplishment of Ferris's massive graphic narrative is its use-verbal and visual--of gender, time, and the body to shift the scale (or unit of analysis) from the individual to the collective, revealing the health impact of intersectional oppressions. This comic amplifies the contribution of graphic medicine by illuminating the power of drawing as a healing process.

My Favorite Thing is Monsters purports to be Karen's sketchbook in all its tangible materiality: the spiral bindings, the blue-lined three-ring-binder punched paper, and the pastiche of sketches, copies of other art works, interpellated images, and mementos that are tucked and paper-clipped into its pages. This sketchbook also incorporates a sporadic daily diary. Within its pages, Ferris's narrative follows its heroine Karen Reyes as she experiences childhood in Chicago of the nineteen sixties, investigates the murder of her beautiful neighbor Anka (which draws her into Anka's past) and navigates the illness and death of her beloved mother. We follow Karen as she moves from the space of her working-class family home through her uptown Chicago neighborhood to her parochial school and finally to the halls of the Art Institute of Chicago. In each environment we watch as the clashing identity positions of her world-gay, trans, straight; white, Latinx, black; rich, middle class, poor-live out the multiple determinants of health and illness. 


\section{Gender}

The gendered violence experienced by Karen, members of her family, and her friends unfolds in the drawings in Karen's sketchbook. As the working-class daughter of a single mother, Karen is bullied, psychologically abused, and almost raped by her schoolmates. Throughout these experiences, she is struggling to grasp her own queer identity. Her brother Deeze is subjected to racist taunts and violence because of his Mexican features, and the sexual and gender norms that trouble Karen torment Deeze as well. He is tender and loving one moment, and abusive in the next. Her black trans friend Frank is mutilated and beaten for his homosexuality and gender non-conformity, her childhood first love Missy is subjected to draconian gender-reprogramming to prevent their intimacy, and her own dying mother experiences the devastating impacts of inadequate access to health care for the cancer that is killing her. Monsters's verbal, visual, and multi-modal narrative is coupled with a mesmerizing ecosystem of drawings rendered in a range of multiple visual styles. ${ }^{2}$ The comic interrupts the individualizing tendency of the graphic pathography by opposing its narrative forward motion to repeated moments of visual stillness which create widely spreading circles of association across time and space. Three examples reveal the ways Ferris accomplishes this shift.

I draw my first example from the graphic narrative's opening sequence which introduces us to Karen's drawing practice. In visual images that cross the barrier between realism and gothic fantasy, Karen figures the psychological violence she experiences at the hands of the normate world: its hatred and persecution of those who fall outside the norm. Karen affirms her queer sexual identity, from the very flyleaf with its heart dripping blood and celebrating her connection to Missy in block letters, M.H. + K.R., to her sketch of the orange red exploding face of the Wolfman on the cover of Renowned Creatures of Movieville, "the best Monster magazine ever!" We see the sketch of her record player as she cues up "Wild Thing" by the Troggs, and we also read her explanation for doing so:

"I turned up the volume to hide what I was doing because . . It would've completely sucked if . . . Mama had come in and found me doing it. . . But I started moaning real loud like Deeze when he used to have his 'boy's dreams." (Ferris, 2018, n.p.)

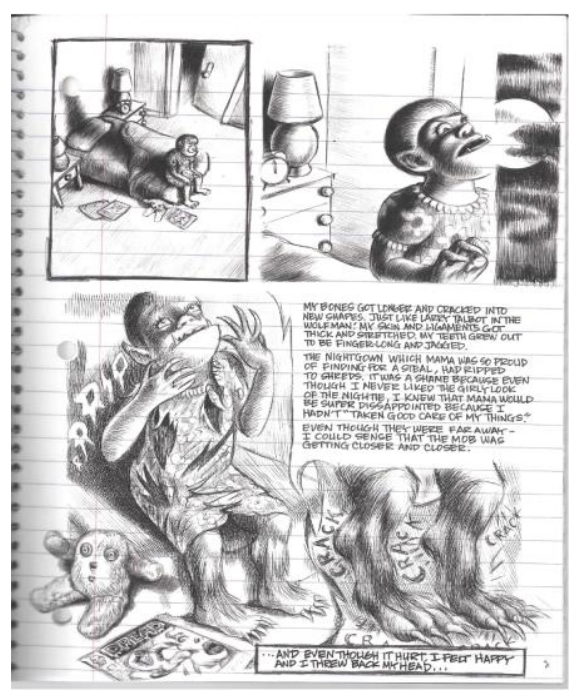

Fig. 1 
When we turn the page, Ferris ratchets up the stakes on female sexuality and gender queerness, as Karen's masturbation, with “Wild Thing” as its audio backdrop, accelerates a shift into the horror genre. (Fig. 1). As the clock registers midnight in the second panel, Karen arches her head back up towards the moon and begins to change: "My bones got longer and cracked into new shapes. Just like Larry Talbot in 'The Wolfman.' . . . The nightgown which Mama was so proud of finding for a steal, had ripped to shreds. It was a shame because even though I never liked the girly look of the nightie, I knew Mama would be super disappointed because I hadn't 'taken good care of my things.' (Ferris, 2018, n.p.) We watch Karen's departure from conventional girlhood in the next panel: Karen stands tall, her fingers sharp claws and her muscular body covered with thick fur. She is the Wolfman, the werewolf, the Monster. Her howl unfurls through the streets of Chicago, where city dwellers march with torches shouting, "Let's smoke that Freak!" and "Kill the Monster!" (n. p.) This introductory sequence braids Karen's own outsider status with the films and fictional works that have fed her imagination. She claims them all as part of her emerging non-binary gender identity.

\section{Time}

In his 2017 interview, Paul Tumey of The Comics Journal also said to Ferris that he found the images in My Favorite Thing is Monsters reminiscent of the work of veteran cartoonist Will Eisner in the late 1930s: "Your pages . . . both work as a kind of poster, a narrative and as a text-image poemthey are both part of the narrative and stand outside it." Ferris responded, "Those pages that defy time are some of my favorites. I refused to learn how to tell time. I did not learn till I was almost 12. I felt it was a dangerous artificial construct. The pages use time in an emotional way, that isn't always linear." (Tumey, 2017) Indeed, as we follow Ferris's exploration of what can hurt and what can heal, we follow a path that is anything but linear.

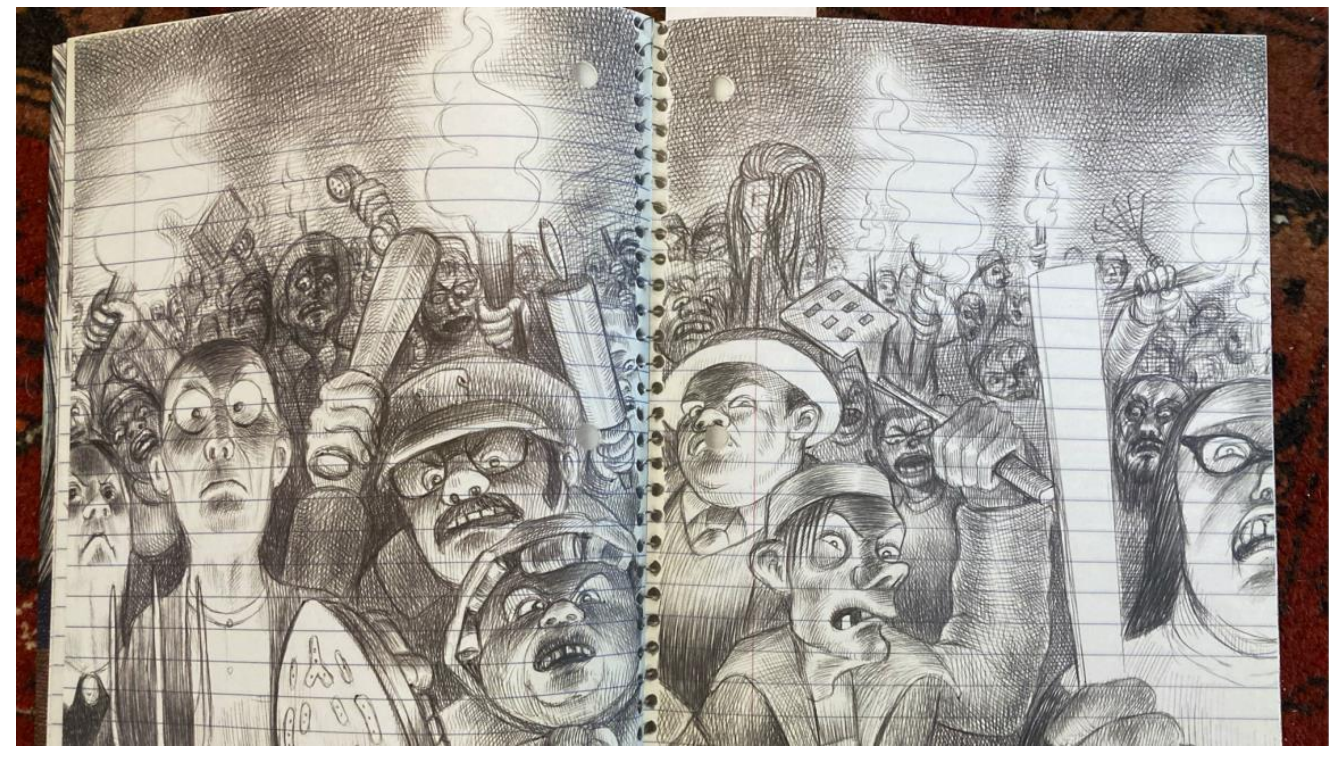

Fig. 2

We begin with a double page spread showing the mob that Karen imagines to be chasing her, her own fantasy recreation of the villagers chasing Frankenstein's monster (Fig. 2). Those timedefying pages create a widening circle of emotional connections through the visual and temporal mashup of cultural icons, movie characters, carnival regulars and the institutional figures from 
Karen's parochial school all pictured in the scene. From left to right we find Grant Wood's "American Gothic"; a baton-wielding police officer and the neighborhood menacing mother, hair in curlers and hot iron in her hand; Stan Laurel and Oliver Hardy; a scary ventriloquist dummy; and finally the nuns from school who threatened spankings with rulers. Faced with this anachronistic crowd of menacing villagers, each of whom threatens Karen's emotional and physical health, she soothes herself by sketching "the cover of the newest Ghastly" given her by her brother Deeze. Paradoxical as this choice of subject may seem to us, Karen is using drawing to master the mob in her mind. When we pause to examine this drawing and the one on the facing page, the mingled genres trigger a range of emotions, their visual images hinting at multiple echoes, repetitions, and resemblances that span time and space.

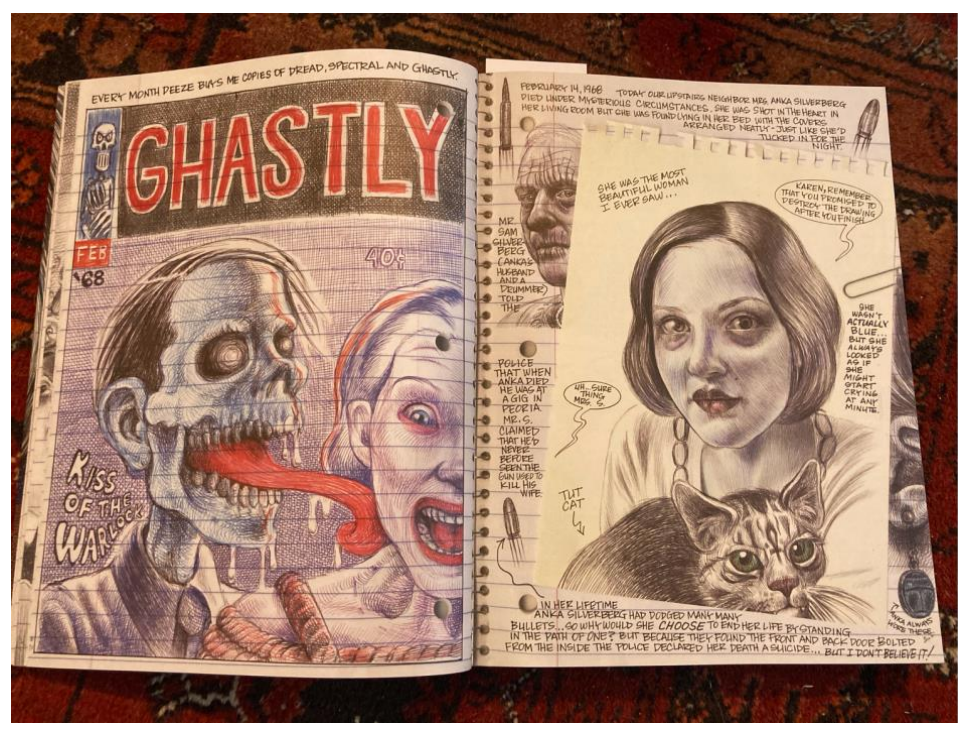

Fig. 3

Karen's sketch of the grotesque cover of the comic book Ghastly Kiss of the Warlock (on the verso page) anticipates a two-page spread that comes more than a hundred pages later in the book, but is drawn from a much earlier time (Fig. 3)(Ferris 2018, n.p.). The time-frame is Weimar Berlin, mid-way through the painful back story of Anka's childhood of neglect and abuse. The scene is Anka's first visit with Herr Schutz, the pedophile to whom she has been sent by "The Big Doctor" as his sexually-based "cure" (Ferris 2018, n.p.).

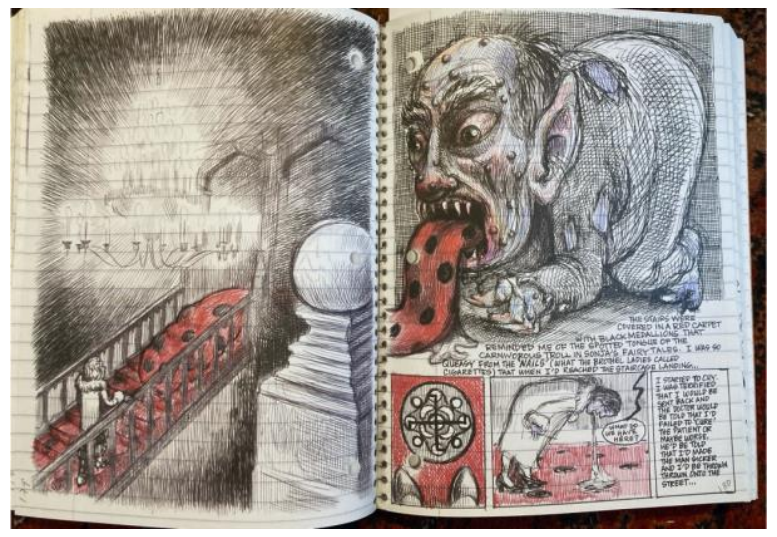

Fig. 4 
Entering Schutz's home, Anka sees the black medallions on the red carpeting and recalls "the spotted tongue of the carnivorous troll in Sonja's fairy tales" (Fig. 4). Anka's emotion-charged memory then propels the visual narrative even farther back into her childhood, when her drug addict mother burned her back with cigarettes and she was soothed by Sonja, the cook of the brothel in which she grew up. Spreading salve on her wounds, Sonja explained, "a weed-like poison ivy-grew inside my sad mad tragic angry bitter mother. Sonja said it burnt my mother and that was why my mother burnt me" (Ferris 2018, n.p.).

Going back to Karen's sketch of Ghastly on the verso, in Fig.3, we find on the recto page Karen's brief diary entry: "Today our upstairs neighbor Mrs. Anka Silverberg died under mysterious circumstances"(Ferris 2018, n.p.). Tucked in at an angle, paper-clipped to the page, is Karen's exquisitely realistic pencil portrait of Anka with the valedictory note, "She was the most beautiful woman I ever saw .. " In a speech balloon, Anka reminds the young artist of the pledge she has made and broken: "Karen, remember that you promised to destroy the drawing after you finish" (Ferris 2018, n.p.).

Like that broken pledge, Karen's sketchbook reveals just what a "dangerous artificial construct" time really is. The composition notebook vibrates ontologically between present, past, and future. The time frame shifts from Karen's present, as she sketches the pulp horrors of Ghastly, to the immanent future of murder and mystery revealed as the holes in the composition notebook become bullet holes in the throat and forehead of a screaming woman whose large eyes, finely etched eyebrows and smooth brown hair resemble Anka's. At the lower left and upper right borders of the portrait on the right, we see two drawings of a whizzing bullet, linked by a wiggly line to the question that will turn Karen into a detective: "In her lifetime Anka Silverberg had dodged many many bullets ... so why would she choose to end her life by standing in the path of one? ... the police declared her death a suicide ... But I don't believe it!"

\section{The Body}

Karen's investigation into Anka's death starts with long talks and listening sessions with Anka's widower, Mr. Sam Silverberg. He plays for Karen a cassette tape of an interview with Anka (seemingly by someone researching holocaust testimony). The words that unspool on the cassette tape and are then transformed into Karen's drawings of Anka's childhood and young adulthood in interwar Berlin trigger a kind of nostalgia, but not in its static or regressive form. Instead, they produce a multi-modal version of "speculative nostalgia, " an aesthetic strategy that, in "its mixture of time, going backwards and forwards, brings the present consumer into a knowable, past moment to create a form of combined and uneven development that mixes past events and affect with present awareness" (Shapiro 2020, 125) They reveal to the reader the intersectional nature of the violence experienced during the Nazi era economic privation and war, Anti-Semitism, sexual violence and genocide.

Examined closely, one double-page spread of a Berlin street scene establishes the body as a site of intersectional violence. The episode begins when Anka is on the threshold of puberty. Her mother sells her to the brothel Madam, who in turn sends her to the owner of a restaurant, purportedly to make a delivery of some carrots. Anka ignores her better judgment and agrees to make the delivery to the restauranteur. In the cassette testimony, she explains why she does this:

There are secret unspoken words that flow from a mother to her child. It starts when the child is inside of her. Because of the secret words, either the child will feel that the door of 
the world is closed to them or that they are welcomed. For the child who isn't welcomed there is always the impulse to oblige the mother ... and leave. This temptation whispers to them all their lives. It tips their better judgement off balance. It causes them to ignore their intuition, to dance at the ends of the chasm. (Ferris 2018, n.p.)

As Anka explains to her interviewer, "In those days, in the years between the first and second war, Berlin was a beautiful but very wounded city . . . Broken bodies \& souls everywhere. . I had to wrap wire around and around the box of carrots to keep hungry hands from reaching in and grabbling" (Ferris 2018, n.p.). The image, a double-page spread of Berlin pedestrians, shows Anka on her way to the pedophile restauranteur. Carrying her box of carrots, she is positioned between a gaudily dressed woman-perhaps a prostitute?--and a man with a horrible facial scar. Anka's placement in the center of this crowded panel establishes sexual violence as one among many of the wounds of war. In the end, schooled by her mother's abuse to respond to the pull towards death, Anka cannot elude her rape by the restauranteur. "Not so fast! I paid for more than a box of carrots ..." he says to her. (Ferris 2018, n.p.)

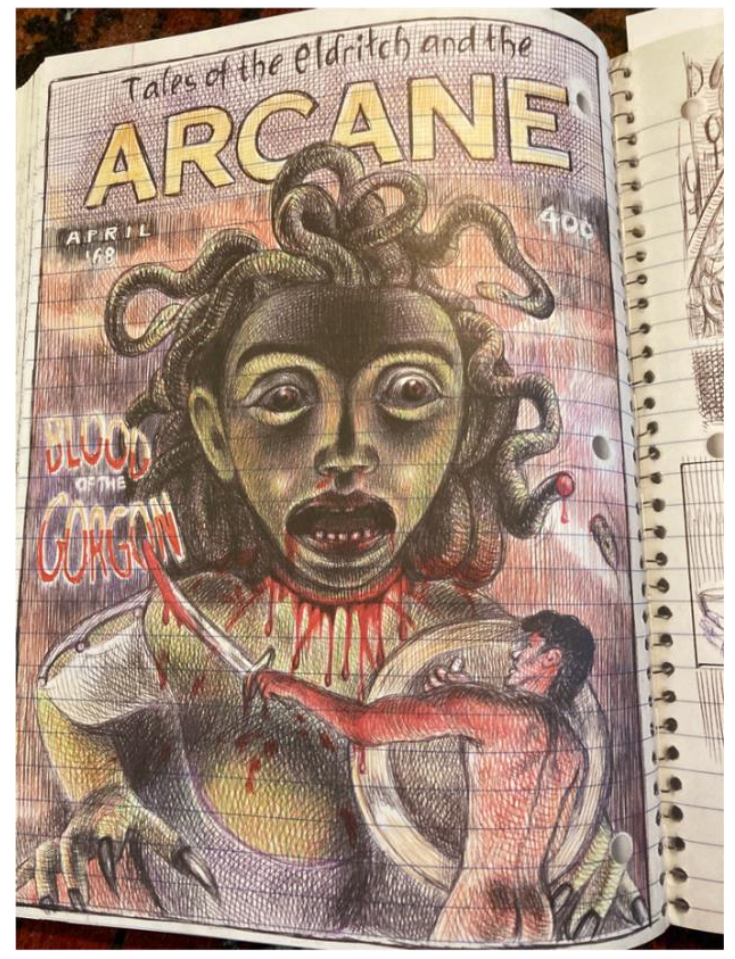

Fig. 5

Abruptly interrupting this story of Anka's abuse, Karen's sketchbook then includes her drawing of the April 1968 issue of Tales of the Eldrich and the Arcane: "Blood of the Gorgon" (Fig. 5). It shows Perseus, with shield and sword, cutting off the head of Medusa, the gorgon. Although the narrative will return to the story of Perseus and the Gorgon, twice told by Anka and her friend, this is our first introduction to the Medusa. To Sigmund Freud, the image of the Medusa spoke of the castrating power of the mother. As he wrote in The Medusa's Head, 
The hair upon Medusa's head is frequently represented in works of art in the form of snakes, and these once again are derived from the castration complex....

The sight of Medusa's head makes the spectator stiff with terror, turns him to stone. Observe that we have here once again the same origin from the castration complex and the same transformation of affect! For becoming stiff means an erection. Thus in the original situation it offers consolation to the spectator: he is still in possession of a penis, and the stiffening reassures him of the fact. (Freud 1922, 273-74)

Despite Freud's certainty that to glimpse the Medusa will devastate any spectator, from matriarchal societies to contemporary feminists the Medusa stands as an emblem of the generative force of authentic female sexuality. In The Laugh of the Medusa (1975) feminist critic Hélène Cixous links the vision of the Medusa to woman's inexhaustible, multimodal, imaginary: "like music, painting, writing: their stream of phantasms is incredible." (876). Cixous argues that such creativity is born in woman's extended exploration of her own body: "a systematic experimentation with the bodily functions, a passionate and precise interrogation of her erotogeneity." Cixous might have been describing the visual and verbal lushness that is Karen Reyes's sketchbook:"this practice, extraordinarily rich and inventive, in particular as concerns masturbation, [which] is prolonged or accompanied by a production of forms, a veritable aesthetic activity, each stage of rapture inscribing a resonant vision" (Cixous 1976,876) Contra Freud, Cixous asserts:

The Dark Continent is neither dark nor unexplorable. It is still unexplored only because we've been made to believe that it was too dark to be explorable.... They riveted us between two horrifying myths: between the Medusa and the abyss. . . Wouldn't the worst be, isn't the worst, in truth, that women aren't castrated, that they have only to stop listening to the Sirens (for the Sirens were men) for history to change its meaning? You only have to look at the Medusa straight on to see her. And she's not deadly. She's beautiful and she's laughing. (Cixous 1976, 876)

Ferris uses the Medusa to hold in tension Anka's double inheritance from her mother: her pull towards self-destruction as well as her hard-earned capacity for self-preservation.

The Medusas of Freud and of Cixous reemerge in the next episodes of Anka's life, which move from a personal story about gender-related violence to a broader encounter with threats that link sexual politics to fascism, revealing the potential power as well as danger that Anka will find in the Medusa. Anka is sold into child prostitution under the control of the "Big Doctor," who calls his home "The Pharmacy." She is given a roommate, aptly named Dolly, whose task it is to "teach [her] about the pharmacy," that is to say, to indoctrinate her in the sexual practices the Big Doctor will require her to provide. The next several pages unveil the true nature of the medicine this so-called pharmacy delivers - sex with underage girls, in truth a Pharmakon, both poison and cure. As the two girls lie in bed together, in a Will Eisner-like double-page narrative spread, Anka tells Dolly the story of Perseus and the Medusa. This version of the Medusa is the story of the Gorgon Karen picked up reading horror comics, in which the blood that drips from one side of the Medusa's head can kill, while that from the other side can cure. ". . . then Perseus picked up Medusa's gory dripping head. The snakes on the left side of her head dripped a dark foul-smelling blood that was poison." (Ferris 2018, n.p.)

This horrifying tale becomes an edifying and even liberating one when Dolly takes over and retells the story to Anka. Reframed, it now reveals the power of female sexuality. "Medusa was the first medicine!" Dolly explains, putting her hand beneath the covers to caress Anka. “The big doctor 
assigned me to be your teacher. . . . If you let me do it, I'll explain everything. After maybe you can just think of it as putting medusa's head back on her body . . . And you might find that you even like it. .." (Ferris, 2018, n.p.). Knowing sexuality only as brutal rape before, Anka now encounters sexual pleasure with Dolly as her guide. She discovers jouissance, gift of the Medusa of Cixous: "I remember that afterwards I undid Dolly's braids and fanned her wavy hair onto her pillow like a halo ..." "Dolly ... you look like Medusa," Anka says. (Ferris 2018, n.p.)

The power of that sexual reframing helps Anka several days later, as she prepares to go on her first "medical" visit: "In the few days that Dolly was my teacher, she taught me that men who prefer young girls are afraid of grown women. Dolly taught me to watch my patient carefully. She said my patient would show me how to 'cure' him and that 'curing' him would make me safe from the darkness in him. My palms were sweating and I was shaking all over, but because of Dolly I didn't feel helpless ..." (Ferris 2018, n.p.). Appalling as it is, Anka's meeting with Herr Schutz also reveals a weakness that Anka exploits in the days to come: his brutality is combined with tenderness. Relying on his restraint as well as his sexual weakness, Anka exerts a power over him that will one day save her life.

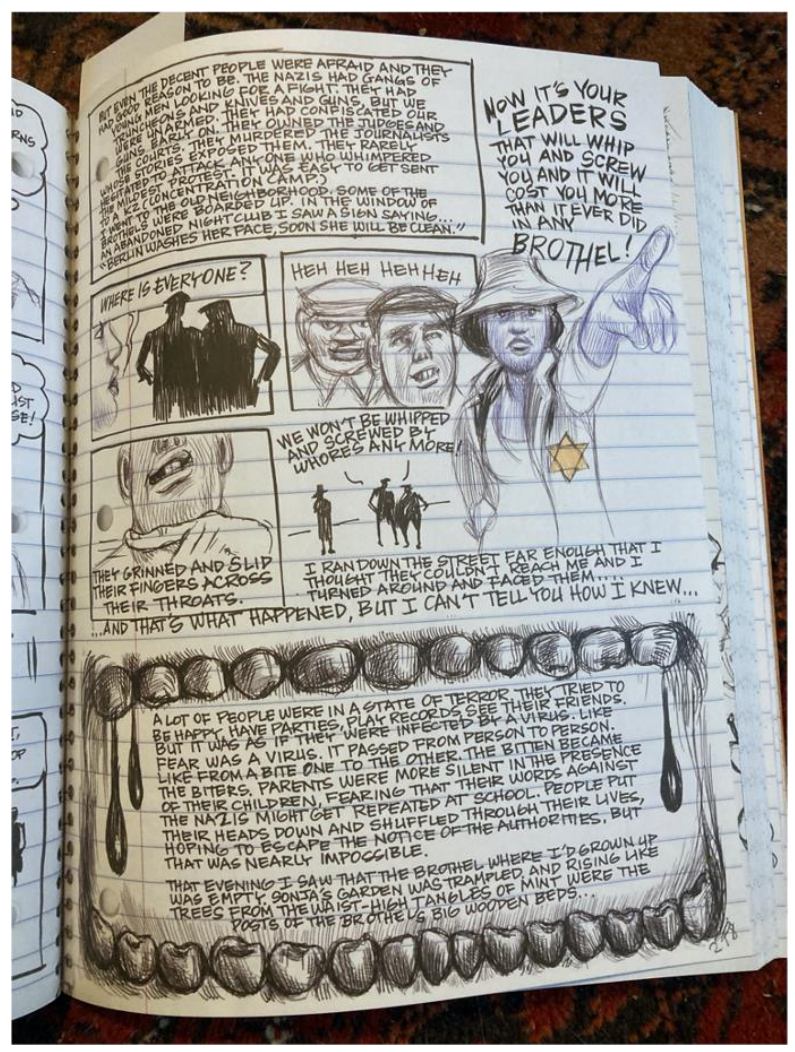

Fig. 6

As the Nazi plan unfolds, Anka is forced to don the gold star, and join her fellow Jews in the ghetto. In a black-and-white image of a mouth dripping blood, Karen represents Anka's emotional state as part of a larger phenomenon in the text within the bloody mouth: "A lot of people were in a state of terror ... it was as if they were infected by a virus (Fig. 6). Like fear was a virus. It passed from person to person. Like from a bite one to the other. The bitten became the biters." (Ferris 2018, n.p.) Ferris's own brush with paralysis from the West Nile Virus informs her emotional portrait 
of Anka's fellow Jews: "People put their heads down and shuffled through their lives, hoping to escape the notice of the authorities, but that was nearly impossible." (Ferris, 2018, 218).

The women of the brothel where Anka lives ultimately fall victim to the Nazis, yet even in suffering they are ignored, as Anka's cassette testimony explains:

Of course when the history books tell of the groups murdered by the Nazis, they never list the prostitutes.... I'm sure the mention of their deaths is considered a stain on the other victims. The attitude is that the lies of prostitutes are worthless. I think it is self-hate. Our world hates anyone who would accept us and our bodies, and our secret desires without reservation. But that is what the ladies taught me. . . to welcome disdained things. (Ferris, 2018, n.p.)

Disdained things: the words speak for so many people we meet In Monsters, as the narrative moves from Anka's memories of the interwar period in Berlin and the Nazi Holocaust to Karen's experiences in the American '6os. Just as Anka is tormented by her mother and abused in a catand-mouse relationship with her pedophile tormentor-turned-protector Herr Schutz, so too Karen is nearly gang raped, saved only by her closest friend Frank. A dead ringer for Frankenstein who is black, gay, and possibly trans, Frank suffers from ostracism, mockery, bigotry, physical injury, and finally devastating emotional pain with the news of Martin Luther King's assassination. Karen's detective journey back to the Nazi era on the trail of Anka's past, like her experience of racial and gender oppression in the 196os, carries the same message: when we find ourselves in the position of stunned witnesses, we need to turn our witnessing into community resistance.

As readers, we do so by embracing the full visual mixture of Monsters, which eschews the conventional comics form of panel and gutter in favor of what Shapiro calls "image spill." He argues that this enables Ferris to make three crucial formal interventions. $(2020,128)$ First, she refuses the "prestige rankings of media" that are so foundational to comics' jockeying for cultural endorsement, embracing instead a range of visual materials from pulp comics to museum holdings without creating a value hierarchy amongst them (Shapiro, 128). Second, she portrays immersion in art as a "cognitive tool," which serves Karen well as a "resource to handle her frequent witnessing of public racial prejudice and the whispers surrounding her family's private tragedy, including her mother's incipient death from cancer" (Shapiro, 130). Third, she invites the reader to join Karen and her friends in plunging headfirst into the drawings that are at the core of Monsters (Shapiro, 133). As we watch the meaning of the Medusa change as the plot develops, we see Karen and Anka learn to claim their own voices and strength despite the many oppressions they experience. Creating a community of care that connects across intersectional oppressions is the core mission of Monsters. ${ }^{3}$

Karen's queer decision to eschew binaries occurs on the unbordered, gutter-free spread of the comics page in a pivotal scene of Monsters. Deeze asks Karen to face herself in a plate glass window. "Karen, you say that you want the truth, look at your reflection," Deeze says, holding her as she is dressed as the Werewolf detective. The poignant scene gathers power from its switchback revelations. As Karen gazes at herself, over five panels, the self she sees changes from the hardboiled tusk-jawed werewolf to what Deeze describes as "a girl! Not Larry Talbot three quarters the way to being the FUCKING WOLFMAN" (360). Despite Deeze's attempt at gender indoctrination, Karen increases the stakes of the debate, and prevails, when she retorts "You're the one who always says that people should get to be who they are! Not who people tell them they are!" “You really aren't a ‘word man' or a 'picture man' are you? I'm like you, because like you, I like ... girls." 
Karen's refusal of this false binary-words versus pictures-resonates with the focus on multimodal pathographies that has been key to the PathoGraphics project, a multi-lingual exploration of the relations between written illness narratives and works of graphic medicine. As Irmela Krüger-Fürhoff and I explain, "the core of our project . . . is to challenge any simple opposition between word and image, an opposition that has historically obscured a broadly shared project of using narrative and aesthetics to serve engagement and activism around the issue of human suffering and pain, and . . to probe the unexamined assumptions that have narrowed the concept of Pathos or pain, and graphē/graphein to the human individual."

\section{Drawing as a Practice}

We can find a powerful exploration of the liminal zone between the drawn and the written in the work of MacArthur award winning cartoonist Lynda Barry. A professor of "interdisciplinary creativity" at the University of Wisconsin-Madison, Barry is the author of many prize-winning books that teach how to release creativity in words and images. Her 2019 Making Comics explores the way new stories come into being (Barry, 2019). Stories happen when we follow images, Barry explains, but not just any images. She means the kind that are "a sort of living snapshot, the kind of memory you can turn around in. . . if you can 'see' it in your mind's eye with your whole body there will be a hint of a story that bids you to follow" (Barry, 2019, 155). Such images generate stories that lend themselves to comics because they move "not from fact to fact but from image to image" (Barry 2019, 155). These stories can work backwards and forwards in time and space, so that "the same walk can contain images from night or day, can switch season, can move forward and backward by years." (Barry 2019, 155)

A striking resemblance connects the works of Emil Ferris and Lynda Barry. Each cartoonist gives us a work that is anything but linear, in which visual images tempt us to enter them physically as embodied experiences, malleable and changing and full of emotion. When I joined a zoom discussion with Ferris sponsored by the Milwaukee Comics Club on November 30, 2020, I asked her whether she was aware of Barry's work. She said regretfully "I have a lot of respect for her but I've never met her," though they had been "this close" (a pinching gesture with her fingers). "I would love to meet her!" she went on. And, in an answer that models artistic sisterhood, she continued, "I think she is amazing ... There were times when I would read her comics and I would have this frisson of recognition. . . she just broke open shame . . .there is a way she energizes her characters that is so unique." 5

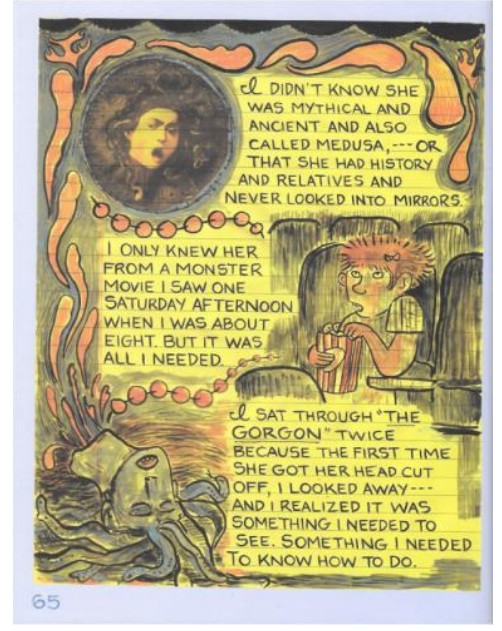

Fig. 7 
Barry also shares Ferris's obsession with the image of the Medusa. Writing in What It Is (2008), ten years before Ferris published Monsters, Barry recalls how she first encountered the Medusa herself in a monster movie one Saturday afternoon. "I sat through the Gorgon twice," she says, "because the first time she got her head cut off, I looked away (Fig. 7). I realized it was something I needed to see, something I need to know how to do." (Barry 2008, 65). From then on she was obsessed with the Gorgon. "Though I knew she didn't exist, the monster I was the most afraid of was The Gorgon. I hated the thought of her, but she was often on my mind. . I believe a lot of kids play with monsters in this way. That most of us had a certain something that really scared us, and seemed to have it in for us. A 'Something" we had to defend ourselves against in secret ways" (Barry, 2008, 63-64). She instinctively sensed that, like Perseus, she needed to decapitate the Medusa. But the reason for that eluded her, she confides; it never occurred to her that she "had a very Gorgon-like mother" (Barry 2008, 66). "We never need certain monsters more than when we are children and a furious woman with terrifying eyes and snakes for hair was the perfect monster for me" (Barry 2008, 66). Barry teaches a kind of radical trust in monsters that is grounded in her own childhood. By telling her own monster story, Barry challenges the reader to similar self-exploration.

What we might call the "Barry zone" is a deeply drawn autobiofictionalographical exploration: it could be labelled (like the old maps) "Here Be Monsters"6. Barry gets into this zone by one of her core exercises, the scribble monster, an exercise we have used in the Graphic Medicine International Collective "Drawing Together" zoom gatherings. Held since the pandemic emerged, these gatherings occur a month, on Sundays. A group of 40 or so people from around the world gather on zoom to draw and talk together. (These events are archived at https://www.graphicmedicine.org/drawingtogether/.). We have sometimes begun these sessions with the "scribble monster" drawing exercise. You scribble something, and then you let your pencil or drawing pen guide you as you turn it into a monster.

For Barry, quick self-encounter is what monster drawing offers: "It takes about two or three minutes to make a scribble monster. It takes years to put two and two together. What if your monsters had something to offer you? An unexpected thing? . . Have mercy on the unspeakable monster who has no other way to tell you it's you" (Barry 2019, 101). Barry's exercise recalls the British psychoanalyst D.W. Winnicott, who played "the squiggle game" with the young girl whose treatment he narrates in his classic case study, The Piggle (1991). He would draw a squiggly line, and then she would follow by drawing her own line. Over the course of many sessions, through these playful interactions, Winnicott was able to help the little girl deal with the trauma and betrayal she had experienced when her mother had a second child. But there's no psychoanalyst in Linda Barry's game, and no patient. You are playing the squiggle game with yourself, and the thing your scribble moves you to create is a monster. As Barry tells us, the monster is what every adult still wants: a toy that plays back and has a life of its own. The scribble monster gives a feeling of open engagement with a character right away, and so drawing monsters allows us to activate our instinct and intuition immediately. Monsters remind us that the improvisational mind is transferrable, that things can come about intuitively, and that both plot and image have a spontaneous core.

\section{Drawing My Own Monsters}

I want to shift, now, to a process-based coda to this analysis of the role of drawing in the works of Emil Ferris and Lynda Barry. The USA went into Covid-19 lockdown in March of 2020. By the time of this writing, December 2020, the Coronavirus has moved to community spread, our hospitals 
are close to being overwhelmed, and people my age continue to be locked down. Back in December 2019, even before the coronavirus pandemic began, I had started the drawing practice Barry explained in her volume, Making Comics. This consists of a two-page exercise, the Daily Diary, carried out in a black and white composition notebook with black flair pen (part of the Barry regime for cartooning). On the left-hand page you list seven things you did, seven things you saw, one question, and one thing you noticed. Then on the right-hand side you choose one of the items you did or saw, and you draw it, putting yourself in the image, before writing about it in the first person in the space below. Barry calls this practice "Celestial Hand Eye Activity," explaining "We might call what we are doing when we use images in this way a form of dreaming-something not quite within our control is suggesting itself and moving our pen forward. Our task is to stay curious and open and in motion until the drawing period is over. . We develop a gradual belief in the spontaneous, ordering forces from which stories appear." (Comics, 11)

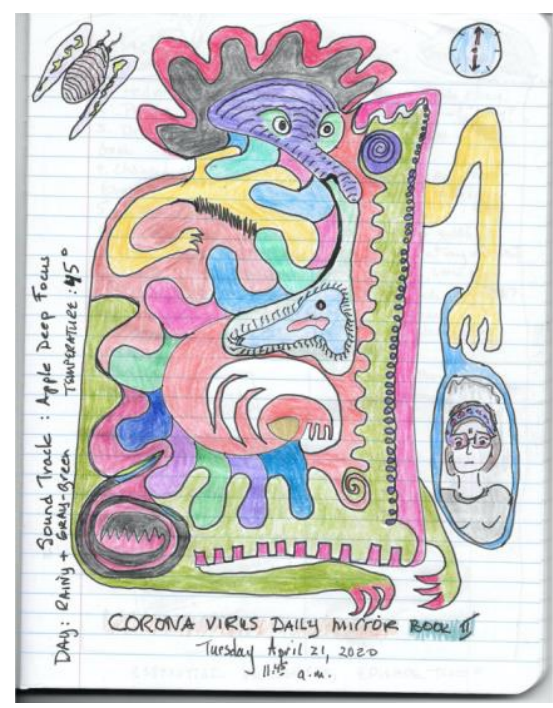

Fig. 8

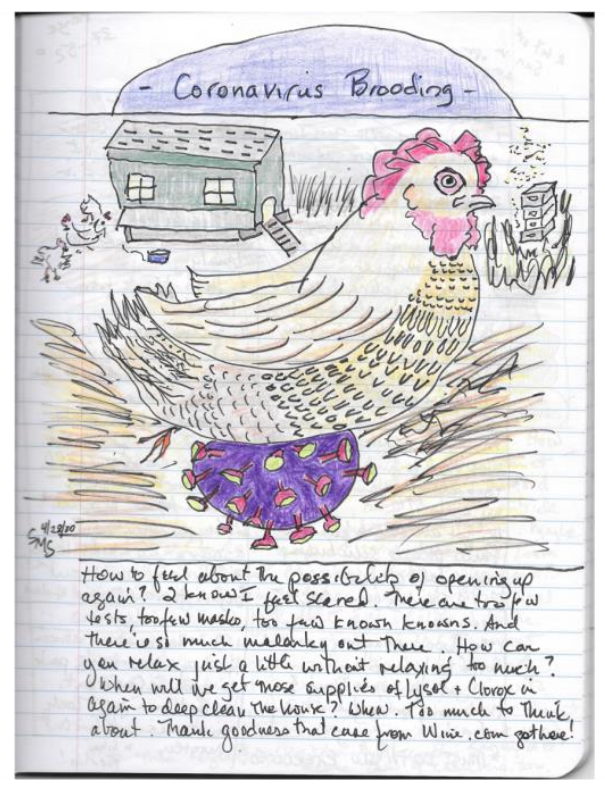

Fig. 9 


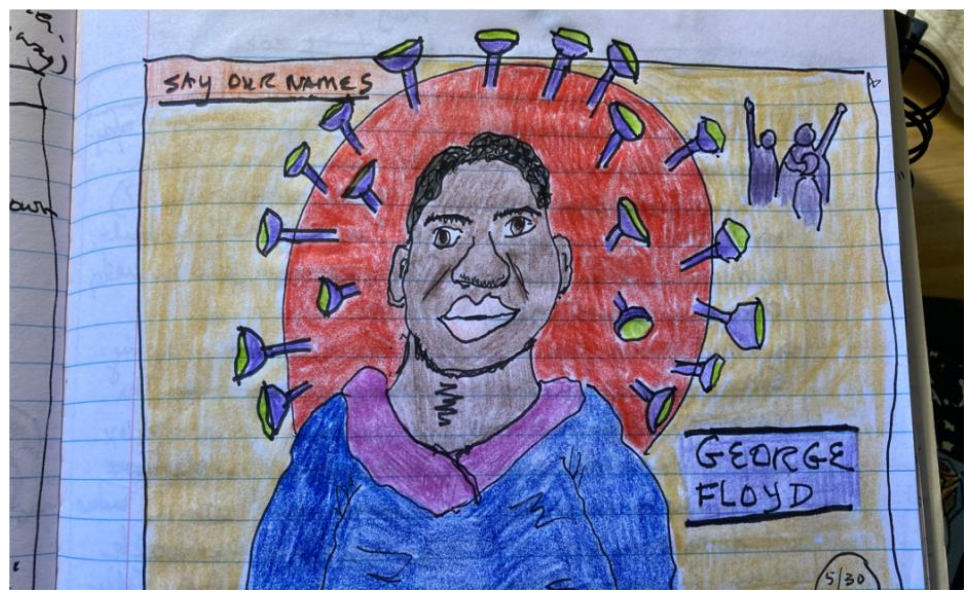

Fig. 10

Barry counsels, "When you are lost, there draw monsters. If you open the way for them monsters will surprise you and this is a reason to draw them." (Barry, 2018, 66). I conclude this essay with some of the monsters that emerged to me as I drew this daily diary. On Tuesday April 21, 2020, I was surprised by this monster that emerged on the first page of the second volume of the Daily Diary: my own Coronavirus Medusa (Fig. 8). Other monsters followed, such as one that recalls my avatar in the Graphic Medicine Manifesto, the chicken, drawn now brooding over a coronavirus egg (Fig. 9). As both Barry and Winnicott would have predicted, I have found versions of myself in the monsters I've drawn: not only the self that broods over an unspeakable fear of the coronavirus but also the self that is wrestling with the murder of George Floyd in Minneapolis on May 25. And on May $31^{\text {st }}$ the self who, though fearful because of my age and risk status, joined a Covid-19-era demonstration in my hometown to protest the police murder of a young black man fighting schizophrenia (Fig. 10). And on November 11, the self that feared for the political health of our nation, wondering: will our democratic process survive? Are we going through a slow-motion coup?

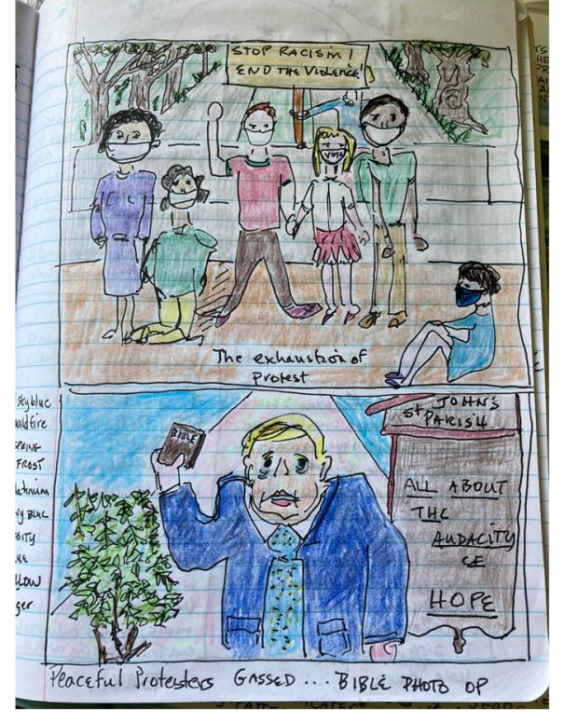

Fig. 10.1 


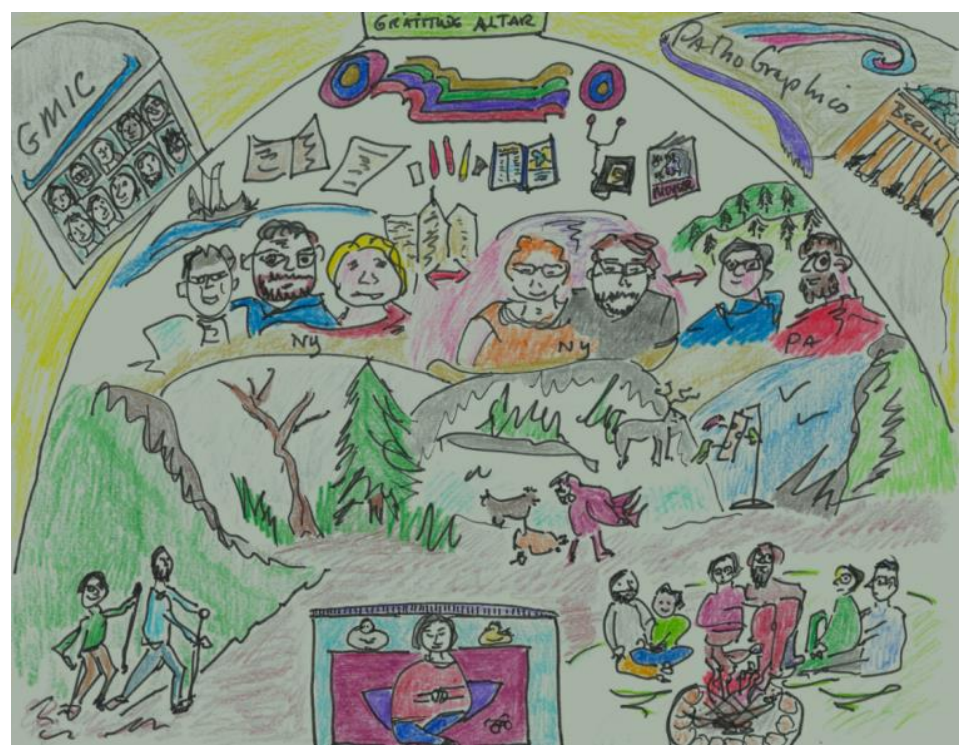

Fig. 11

Finally, with the other participants in the Graphic Medicine zoom drawing together session, I drew a "gratitude altar" following the prompt of our colleague, Comic Nurse a.k.a. MK Czerwiec (Fig.11). As Czerwiec explained, in comments available in full on the graphicmedicine.org website, there is a powerful connection between the practice of drawing, the practice of healing, and the practice of activism:

In many ways, this year has been unlike any year we have known previously. In the face of all of the loss, sadness, injustice, anxieties, and pain in the world that have been so present, making a list of what we are grateful for as we near the close of this year seemed uniquely important. A quick caveat: Let me say that do I approach talking about and taking stock of one's sense of gratitude with a critical eye. The concept of gratitude has been a bit co-opted, even commodified, for self-help schemes. Gratitude has also been used as a tool to oppress and squelch calls for justice. That is not what our work here today seeks to do. My hope is that as we consider gratitude today, let us seek to remind ourselves of that which strengthens us in our calls for justice, peace, and integrity. (Czerwiec, 2020)

As I drew that gratitude altar, I was able to celebrate what has kept me well during these last ten months: meditation, my family, my friends near and far, the landscape around my house, the various multi-modal strategies available to me even during the pandemic to express myselfwriting and drawing and reading and listening to books on Audible--and finally the communities of the Graphic Medicine International Collective and of PathoGraphics. We haven't come to the end of Covid-19 nor of the deadly Presidential administration whose violence of inaction has produced the terrible viral spread with which we are all now dealing, and I haven't reached the end of this daily diary journey. But during the months I have been keeping what has by now moved into a fourth volume, I have learned well the lesson Deeze taught Karen Reyes, and Lynda Barry 
taught me: that "drawing through" hard things—even an illness on the scale of a global pandemiccan provide solace and even a vision of community.

\section{Notes}

'I use the term graphic narrative here, interchanging it with comic, because I am persuaded by Stephen Shapiro's observation that in this moment when "the novel-form is losing its dominance in favor of other forms," the term "graphic narrative" is preferable to graphic novel "in order to underscore its functionality precisely because of its not-novelness." Stephen Shapiro, "Speculative Nostalgia and Media of the New Intersectional Left: My Favorite Thing Is Monsters", in T. Lanzendörfer and C. Norrick-Rühl (eds), The Novel as Network: New Directions in Book History: 119-136, 120. https://doi.org/10.1007/978-3-030-53409-7_8.

${ }^{2}$ I draw this basic point from Alison Bechdel's jacket blurb on My Favorite Thing is Monsters Vol. 1 (Seattle, WA: Fantagraphics Books, 2019).

${ }^{3}$ As he works through these points in his insightful essay, "Speculative Nostalgia," Stephen Shapiro argues that Ferris connects artistic immersion with the "Stendhal effect" motif in which visual media serve as a space one can enter to gain a whole-body healing (Shapiro, 133).

4https://www.geisteswissenschaften.fu-

berlin.de/friedrichschlegel/assoziierte_projekte/Pathographics/sl_2_ABOUT/index.html. PathoGraphics: Narrative, Aesthetics, Contention, Community, eds. Susan M. Squier and Irmela Marei Krüger-Fürhoff (University Park: Penn State University Press, 2020), 3.

${ }^{5} \mathrm{My}$ transcription from memory of the Milwaukee Comics Forum meeting with Emil Ferris, November 30, 2020, 7-10 pm CST.

${ }^{6}$ This is Barry's term for the melded exploration of fact and fiction, word and image, that occurs when we let an image draw us along into a story. She used the term to describe her 2002 volume, One Hundred Demons. Andrew D. Arnold, "Making It Up as You Go Along," Time Friday October 18, 2002.

\section{References}

Barry, L. (2008). What It Is. Drawn \& Quarterly: Toronto.

Cixous, H. (2010). Laugh of the Medusa. OUP

Crenshaw, K. (1989). Demarginalizing the Intersection of Race and Sex: A Black Feminist Critique of Antidiscrimination Doctrine Feminist Theory and Antiracist Politics. University of Chicago Legal Forum: Vol. 1989 , Article 8

Czerwiec, M. K. (2020, November 29). Drawing Together 18: Gratitude. Graphicmedicine. https://www.graphicmedicine.org/drawing-together-18-gratitude/

Ferris, E. (2018). My favorite thing is monsters. Seattle, WA: Fantagraphics Books.

Freud, S. (1922). Medusa's Head. The Standard Edition of the Complete Psychological Works of Sigmund Freud, Volume XVIII (1920-1922): Beyond the Pleasure Principle, Group Psychology and Other Works, (pp. 273-274).

Shapiro, S. (2020). Speculative Nostalgia and Media of the New Intersectional Left: My Favorite Thing Is Monsters. In T. Lanzendörfer and C. Norrick-Rühl (Eds.), The Novel as Network: New Directions in Book History (pp. 119-136), 120. Palgrave Macmillan. https://doi.org/10.1007/978-3-030-53409-7_8.

The Bite that Changed my Life. (2017, February 08). Retrieved March 02, 2021, from https://www.chicagomag.com/Chicago-Magazine/February-2017/Emil-Ferris-The-Bite-That-Changed-MyLife/

Thielman, S. (2017, February 20). Emil Ferris: 'I didn't want to be a woman - being a monster was the best solution'. The Guardian. https://www.theguardian.com/books/2017/feb/2o/emil-ferris-my-favorite-thing-ismonsters-graphic-novel 
Tumey, P. (2017, February 22). The Emil Ferris Interview: Monsters, Art and Stories (Part 2). Retrieved March 02, 2021, from http://www.tcj.com/the-emil-ferris-interview-monsters-art-and-stories-part-2/

\section{Author note}

Susan Merrill Squier is Brill Professor Emeritus of Women's, Gender and Sexuality Studies and English at Penn State University. Her books include Epigenetic Landscapes: Drawings as Metaphor, Graphic Medicine Manifesto, (with MK Czerwiec et. al.), Liminal Lives: Imagining the Human at the Frontiers of Biomedicine, and PathoGraphics: Narrative, Aesthetics, Contention, Community, eds. Susan M. Squier and Irmela Marei Krüger-Fürhoff. She is co-editor of the Graphic Medicine book series at Penn State University Press, a member of the Graphic Medicine collective, and serves as co-organizer of the annual international Graphic Medicine conferences. 